\title{
Implementasi Konsep \\ "Mabadi Khaira Ummah Nahdlatul Ulama" Sebagai Bentuk Moderasi Islam di Kabupaten Nganjuk
}

\author{
Muhamad Umar Fauzi, M.Pd.I \\ umarfauzim@gmail.com \\ (STAI MIFTAHUL 'ULA NGANJUK)
}

\begin{abstract}
Abstrak
Nahdlatul Ulama merupakan ormas terbesar di Indonesia. Keberadaan Nahdlatul Ulama di Indonesia merupakan keniscayaan yang harus dipertahankan demi keutuhan NKRI. Sikap moderat yang dimiliki oleh umat Islam merupakan suatu konsep yang harus dilakukan agar keberlangsungan tatanan kehidupan yang harmonis antara sesama umat Islam dan sesama umat manusia dalam bernegara dapat terjaga dengan baik. Nahdlatul Ulama didirikan atas prakarsa para Ulama Nusantara yang memiliki sikap moderat sehingga gerakan-gerakan serta kegiatan-kegiatan yang dilakukan dapat diterima dengan baik oleh masyarakat Indonesia. Untuk mewujudkan tatanan kehidupan yang lebih sejahtera maka Nahdlatul Ulama melakukan berbagai gerakan sosial keagamaan maupun pengembangan ekonomi umat. Gerakan ini merupakan implementasi dari konsep dasar NU yakni Mabadi Khaira Ummah. Dengan Implementasi Mabadi

Khaira Ummah diharapkan membawa dampak yang positif bagi kehidupan beragama dan bermasyarakat di Indonesia.
\end{abstract}

Tujuan dari Penelitian ini adalah (1) Untuk mengungkap prosedur Implementasi Mabadi Khaira Ummah NU di Kabupaten Nganjuk.(2) Mendeskripsikan Relevansi Konsep "Mabadi Khaira Ummah NU” dan Moderasi Islam di Kabupaten Nganjuk(3) Untuk mengkaji dampak Implementasi Mabadi Khaira Ummah NU di Kabupaten Nganjuk

Penelitian ini berusaha mengungkap bagaimanakah Implementasi Konsep Mabadi Khaira Ummah NU di daerah ini,Penelitian ini merupakan penelitian kualitatif. Dalam penelitian, sumber data ada dua, yaitu manusia dan bukan manusia. Data dalam penelitian ini, berupa segala sesuatu yang berbentuk data deskriptif naratif yang diperoleh melalui sejumlah prosedur penelitian. Data penelitian ini, diperoleh dari sumber data melalui; (a) wawancara mendalam (indepth interview) dengan pendekatan purposive sampling (informan ditentukan terlebih dahulu) dan Snowball sampling (pengembangan informan sesuai dengan kebutuhan data di lapangan).Teknik analisis data penelitian ini menggunakan analisis model interaktif yang terdiri dari, yaitu; (1). Reduksi data (pemilihan data sesuai tema) (2). Display data (penyajian data) serta (3). Penarikan kesimpulan/verifikasi Keabsahan DataKeabsahan data menggunakan teknik triangulasi. Triangulasi adalah teknik pemeriksaan keabsahan data yang memanfaatkan sesuatu yang lain di luar data itu untuk keperluan pengecekan atau sebagai pembanding terhadap data itu. 
Kesimpulan penelitian ini yakni :Penerapan Sikap kejujuran oleh warga NU ditunjukkan dalam hal pengelolaan keuangan dalam melaksanakan suatu kegiatan. Kejujuran juga ditanamkan sejak dini oleh warga NU melalui pendidikan formal, non formal dan informal. Nahdlatul Ulama telah memiliki lembaga pendidikan formal yang dikelola melalui LP pelaksanaan sikap AlAmanah wal Wafa' bil Ahditercermin dalam sikap dan perbuatan pengurus $N U$ yang dapat dipercaya, setia, dan menepati janji sesuai dengan apa yang mereka ucapkan ketika di bai'at sebagai pengurus NU. kegiatan kontrol terhadap pemerintahan daerah. Nahdlatul Ulama memberikan masukan dan mengingatkan pemimpin.warga NU bergotong royong dalam mensukseskan setiap kegiatan yang positif. Yakni ketika ada kegiatan pengajian umum, kegiatan sosial dan kemasyarakatan serta kegiatan lainnya. Amaliyah yang dilaksanakan secara turun-temurun ini dilaksanakan secara terus-menerus dan Istiqomah.

\section{A. Moderasi Islam}

Moderasi dalam Islam telah memberikan "jaminan" ruang hidup abadi ajaran agama ini hingga akhir zaman. Keajegan pokok dan kelenturan dalam cabang ajaran Islam, menjadikannya akan senantiasa mampu beradaptasi dengan situasi apapun di segala zaman dalam keadaan apapun. "Shalehun likulli zaman hua makan" / ajaran-ajaran pokok yang ajeg (tsawabit) dan cabang-cabang yang fleksibel (murunah) telah memberikan ruang yang brgitu lebar bagi adanya ijtihad dalam Islam sehingga bisa dipastikan ajaran ini tidak mengalami kejumudan.

Makna moderasi Islam adalah Pluralitas yang sesuai dengan kadar yang seharusnya, suatu ke khasan tersendiri dari beberapa unsur yang disatukan oleh faktor kesatuan Islam, serta suatu kemajemukan dari madzhab-madzhab dan aliran-aliran yang diakui oleh konsep Islam yang merangkumnya, juga keunikan yang bermacammacam dalam kerangka konstanitas persatuan Islam. Faktor "Islam yang merangkum" ini tidak hanya terpaku pada tataran Aqidah Islam saja, namun juga menjelajahi tatarantataran peradaban, budaya, dan aturan nilai keimanan yang menyentuh non muslim dalam tataran-tataran yang beragam dan bermacammacam di bawah faktor kesatuan Islam. Hal itu menjadikan pluralitas Islam terus berkembang serta membangun kekhasan masingmasing, sambil masing-masing pihak (elemen-elemen yang berbeda dan unsure-unsur yang 
beragam itu) menjaganya dengan ruh Islam, warna Islam, yang merupakan kesinambungan dari cabang-cabang pohon yang baik dari kalimat Islam, ajaran Allah SWT kepada Rasulnya dan lanjutnya pengajaran Rasulullah kepada seluruh alam.

Dari kaca mata seperti itu dan dengan metodologi tersebut, Islam melihat pluralitas sebagai sistem kemajemukan Islam dalam kerangka kesatuan Islam. ${ }^{1}$ Moderasi merupakan jalan pertengahan, dan ini sesuai dengan inti ajaran Islam yang sesuai dengan fitrah manusia. Oleh karena itu, umat Islam disebut ummatan washathan, umat yang serasi dan seimbang, karena mampu memadukan dua kutub agama terdahulu, yaitu Yahudi yang terlalu membumi dan Nashrani yang terlalu melangit.

Hal ini terbukti dengan adanya perpindahan arah kiblat yang asalnya menghadap Masjidil Aqsha yang ada di Palestina berpindah menjadi menghadap Masjidil Haram yang ada di Makkah. Ini membuktikan kemandirian dan kemurnian ajaran Islam yang dibawa oleh Nabi Muhammad SAW yang tidak terpengaruh oleh agama terdahulu yang mengagungkan Masjidil Aqsha. Dengan tegas hal ini diungkapkan oleh Alquran dalam surat al-Baqarah ayat 143:

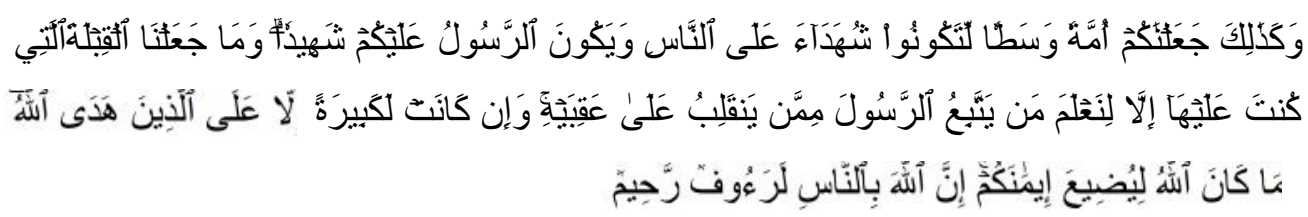

"Dan demikian (pula) Kami telah menjadikan kamu (umat Islam), umat yang adil dan pilihan agar kamu menjadi saksi atas (perbuatan) manusia dan agar Rasul (Muhammad) menjadi saksi atas (perbuatan) kamu. Dan Kami tidak menetapkan kiblat yang menjadi kiblatmu (sekarang) melainkan agar Kami mengetahui (supaya nyata) siapa yang mengikuti Rasul dan siapa yang membelot. Dan sungguh (pemindahan kiblat) itu terasa amat berat, kecuali bagi orang-orang yang telah diberi petunjuk oleh Allah; dan Allah tidak akan menyia-nyiakan imanmu. Sesungguhnya Allah

\footnotetext{
${ }^{1}$ Imarah. Muhammad.1999.Islam dan Pluralitas.Depok. Gema Insani, Hal:12
} 
122 - 147 | Tafhim Al-‘Ilmi, September 2019

Maha Pengasih lagi Maha Penyayang kepada manusia” (QS. AlBaqarah:143)

Sikap Moderat yang seharusnya menjadi nilai yang sangat baik yang merupakan ciri agama Islam ternyata tidak dipahami dan diamalkan oleh seluruh umat Islam. Hal ini terbukti dengan adanya gerakan keagamaan yang ekstrim dan mereka meyakini bahwa apa yang mereka lakukan itu adalah sebuah kebenaran. Gerakan keagamaan tumbuh sebagai reaksi terhadap fenomena penurunan dan penghilangan peran politik dan kultural agama dalam masyarakat sekuler modern serta mereposisi peran agama dengan berbagai pendekatan dan cara yang dipakainya. Dampaknya, kebangkitan berbagai gerakan baik yang liberal, moderat, maupun fundamentalistik. Hamper di semua agama dunia terlahir gerakan fundamentalistik (religious fundamentalism), yang meyakini bahwa perubahan perlu dilakukan secara fundamental untuk mewarnai dunia menjadi religious dan menyelamatkan ajaran agama dari proses annihilasi dan separasi agama dari tatanan kehidupan. Walau gerakan fundamentalisme agama tidak semua menggunakan kekerasan, namun pada umumnya gerakan fundamentalis cenderung menggunakan cara kekerasan (violent means) sebagai alat perjuangannya.

Pada beberapa dekade terakhir, terutama sejak berakhirnya perang dingin antara Amerika dan Uni Sovyet, terjadi akselerasi pertumbuhan faham dan gerakan "Islamisme". 2 ReIslamisasi secara koeksidensial dalam berbagai model yang mengusung nilai dasar humanitas(humanisme), sistem pemerintahan sekular dan penerapan sistem demokrasi liberal. Islam radikal, kemudian cenderung menggagas konsep Khilafah Islamiyah dan penerapan syariat Islam sepenuhnya. Sedang Islam moderat, memposisikan pada titik tengah baik dalam aspek idiologi maupun sistem politiknya. Detail karakteristik antara Islam liberal, moderat dan radikal bisa dilihat dalam table berikut:

\footnotetext{
${ }^{2}$ The Many Faces of Political Islam: Religion and Politich in the Muslim World, hal.41-42
} 
Tabel 1.

Karakteristik Islam Radikal, Liberal, dan Moderat. ${ }^{3}$

\begin{tabular}{|c|c|c|c|}
\hline ASPEK & $\begin{array}{l}\text { ISLAM } \\
\text { RADIKAL }\end{array}$ & $\begin{array}{l}\text { ISLAM } \\
\text { MODERAT }\end{array}$ & $\begin{array}{l}\text { ISLAM } \\
\text { LIBERAL }\end{array}$ \\
\hline $\begin{array}{l}\text { Ideo-political } \\
\text { Spectrum }\end{array}$ & $\begin{array}{l}\text { Left-wing } \\
\text { Movement } \\
\text { (Gerakan sayap } \\
\text { kiri) }\end{array}$ & $\begin{array}{l}\text { Middle, Centrist } \\
\text { Movement } \\
\text { (Gerakan Garis } \\
\text { Tengah) Berada } \\
\text { pada posisi tengah, } \\
\text { "middle position", } \\
\text { "centrist", dan "“ } \\
\text { mainstream". }\end{array}$ & $\begin{array}{l}\text { Right- Wing } \\
\text { Movement(Gerakan } \\
\text { Sayap Kanan) }\end{array}$ \\
\hline World-View & $\begin{array}{lr}\text { Islam } & \text { adalah } \\
\text { agama } & \text { kaffah; } \\
\text { Umat } & \text { Islam } \\
\text { adalah kesatuan } \\
\text { (ummatan } \\
\text { wahidatan); }\end{array}$ & $\begin{array}{l}\text { Islam } \\
\text { rahmatan } \\
\text { 'alamin; } \\
\text { Manusia/umat } \\
\text { bersifat plural; } \\
\text { Manusia memiliki } \\
\text { kebebasan untuk } \\
\text { memilih }\end{array}$ & \begin{tabular}{lr}
\multicolumn{3}{c}{ Agama merupakan hak } \\
pribadi, Islam adalah \\
rahmatan lil 'alamin \\
dan agama, untuk \\
kemanusiaan; & Islam \\
adalah agama rasional.
\end{tabular} \\
\hline $\begin{array}{l}\text { Keyakinan } \\
\text { Kebenaran }\end{array}$ & $\begin{array}{l}\text { Hanya adalah } \\
\text { satu kebenaran } \\
\text { absolut; }\end{array}$ & $\begin{array}{l}\text { Kebenaran } \quad \text { tidak } \\
\text { tunggal absolut } \\
\text { dan relative; }\end{array}$ & $\begin{array}{l}\text { Kebenaran itu relative, } \\
\text { tergantung ruang dan } \\
\text { waktu, dan ratio } \\
\text { sebagai "penimbang } \\
\text { kebenaran" }\end{array}$ \\
\hline $\begin{array}{l}\text { Sumber } \\
\text { Kebenaran }\end{array}$ & $\begin{array}{lr}\text { Al-Qur'an, } & \text { As } \\
\text { Sunnah } & \text { dan } \\
\text { tradisi Salafy } & \\
\end{array}$ & $\begin{array}{l}\text { Al-Qur'an, As } \\
\text { Sunnah, Ijmak, dan } \\
\text { Qiyas }\end{array}$ & $\begin{array}{ll}\text { Kekuatan } & \text { Rasio } \\
\text { melalui Ijtihad } & \end{array}$ \\
\hline Visi & 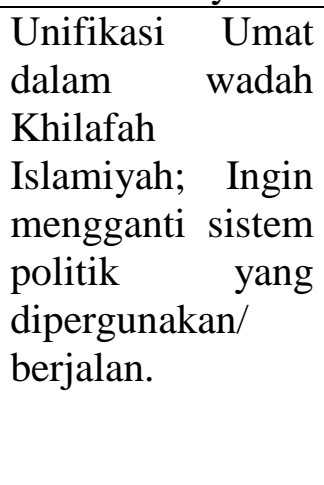 & $\begin{array}{l}\text { Mempertahankan } \\
\text { sistem politik yang } \\
\text { diberlakukan; } \\
\text { mengembangkan } \\
\text { komunitas muslim } \\
\text { (Islamic } \\
\text { Community), yang } \\
\text { multi kultural, } \\
\text { hargai glokalitas, } \\
\text { harmonis. }\end{array}$ & $\begin{array}{l}\text { Mengembangkan umat } \\
\text { toleran, damai } \\
\text { multicultural, } \\
\text { pluralistic dalam } \\
\text { bingkai negara secular. }\end{array}$ \\
\hline Tujuan & $\begin{array}{l}\text { Purifikasi ajaran, } \\
\text { rejeksi bid'ah dan } \\
\text { khurafat; }\end{array}$ & $\begin{array}{l}\text { Mengembangkan } \\
\text { komunitas Islam } \\
\text { (Islamic }\end{array}$ & $\begin{array}{l}\text { Membangun "Global } \\
\text { civil society" } \\
\text { tatanan hidup yang }\end{array}$ \\
\hline
\end{tabular}

${ }^{3}$ Choirul Fuad Yusuf. Nasionalisme dalam Teks Keagamaan Indonesia Masa Depan. Jakarta.Jurnal Lektur. 2017. Hal:499 
124 - 147 | Tafhim Al-'Ilmi, September 2019

\begin{tabular}{|c|c|c|c|}
\hline & $\begin{array}{l}\text { Penolakan } \\
\text { budaya Barat; } \\
\text { Mendirikan } \\
\text { negara Islam ( } \\
\text { Islamic State); } \\
\text { Purifikasi dunia. }\end{array}$ & $\begin{array}{l}\text { Community) yang } \\
\text { multi kultural, } \\
\text { hargai glokalitas, } \\
\text { harmonis. }\end{array}$ & $\begin{array}{l}\text { harmoni, } \\
\text { berbasis } \\
\text { humanis. }\end{array}$ \\
\hline Target & $\begin{array}{l}\text { Terwujudnya } \\
\text { Islam murni, } \\
\text { sesuai Al-Qur'an } \\
\text { Assunnah dan } \\
\text { Salafy. }\end{array}$ & $\begin{array}{l}\text { Terwujudnya Islam } \\
\text { "yang damai" } \\
\text { toleran, harmonis" }\end{array}$ & $\begin{array}{l}\text { Terwujudnya } \\
\text { masyarakat madani( } \\
\text { civil society) yang self- } \\
\text { directed, toleran, } \\
\text { harmonis. }\end{array}$ \\
\hline $\begin{array}{l}\text { Instrumen } \\
\text { Hukum }\end{array}$ & $\begin{array}{l}\text { Syariat Islamiyah. } \\
\text { Ingin mengganti } \\
\text { sistem hukum } \\
\text { negara dengan } \\
\text { "Syariat } \\
\text { Islamiyah". }\end{array}$ & $\begin{array}{l}\text { Menerima dan } \\
\text { mengembangkan } \\
\text { "rule of law" yang } \\
\text { diberlakukan } \\
\text { negara. }\end{array}$ & \\
\hline $\begin{array}{l}\text { Metode } \\
\text { pencapaian } \\
\text { tujuan }\end{array}$ & $\begin{array}{l}\text { Penggunaan } \\
\text { "Hard-strategy" } \\
\text { dengan } \\
\text { menerapkan } \\
\text { konsep jihad dan } \\
\text { halalkan segala } \\
\text { cara untuk } \\
\text { pencapaian } \\
\text { tujuan. }\end{array}$ & $\begin{array}{lr}\text { Penggunaan } & \text { "Soft } \\
\text { Strategy" melalui } \\
\text { dakwah } & \text { dan } \\
\text { pendidikan. } \\
\text { Pendekatan } \\
\text { dakwah, } \\
\text { pendidikan dan } \\
\text { cara akulturatif- } \\
\text { sepanjang tidak } \\
\text { kontradiktif } \\
\text { dengan ajaran } \\
\text { dasar. }\end{array}$ & $\begin{array}{lr}\text { Penggunaan } & \text { "Soft } \\
\text { Strategy" } & \text { melalui: } \\
\text { disseminasi, } & \\
\text { sosialisasi, } & \text { publikasi } \\
\text { doktrin } & \text { melalui } \\
\text { penguatan } & \text { jaringan } \\
\text { internasional. } & \end{array}$ \\
\hline $\begin{array}{l}\text { Sikap dan } \\
\text { posisi politik }\end{array}$ & $\begin{array}{l}\text { Memposisikan } \\
\text { sebagai luar"main } \\
\text { stream"; } \\
\text { Berupaya } \\
\text { menjatuhkan } \\
\text { rezim dan } \\
\text { sistemnya; } \\
\text { Menolak } \\
\text { konsepsi; rule of } \\
\text { law” demokrasi } \\
\text { liberal; dukung } \\
\text { struktur } \\
\text { masyarakat } \\
\text { monokultur; } \\
\text { menolak } \\
\text { kesetaraan bagi } \\
\text { semua; }\end{array}$ & $\begin{array}{l}\text { Memposisikan } \\
\text { pada "titik posisi } \\
\text { tengah", berada } \\
\text { pada kelompok } \\
\text { main stream atau } \\
\text { mayoritas } \\
\text { kepemelukan } \\
\text { agama, } \\
\text { mendukung } \\
\text { kebijakan } \\
\text { keberagamaan } \\
\text { pemerintah/negara; } \\
\text { Dukung struktur } \\
\text { masyarakat } \\
\text { majemuk; Loyal } \\
\text { pada pemerintah; } \\
\text { dukung gagasan }\end{array}$ & $\begin{array}{l}\text { Memposisikan pada } \\
\text { posisi "luar main } \\
\text { stream", berada pada } \\
\text { posisi ekstrem (kanan); } \\
\text { Mengembangkan } \\
\text { demokrasi liberal, hak } \\
\text { asasi, dan etika } \\
\text { secular, membela } \\
\text { kelompok minoritas } \\
\text { (marginal community); } \\
\text { memiliki dan } \\
\text { mengembangkan } \\
\text { jaringan internasional; } \\
\text { Menerima dan } \\
\text { memperjuangkan } \\
\text { kebebasan, kesetaraan } \\
\text { bagi semua. }\end{array}$ \\
\hline
\end{tabular}




\begin{tabular}{|c|c|c|c|}
\hline & $\begin{array}{l}\text { akomodatif bagi } \\
\text { sistem } \\
\text { pemerintahan } \\
\text { universal. }\end{array}$ & $\begin{array}{l}\text { pluralism atau } \\
\text { multikulturalisme; } \\
\text { pertahankan negara } \\
\text { berdaulat. }\end{array}$ & \\
\hline Pola ritual & $\begin{array}{l}\text { Rutinitas, } \\
\text { simbolik, kaku } \\
\text { dan fanatik. }\end{array}$ & $\begin{array}{l}\text { Rutinitas } \\
\text { modifikatif, adaptif } \\
\text { akomodatif }\end{array}$ & Personal, rasional \\
\hline $\begin{array}{l}\text { Sikap } \\
\text { Pemeluk }\end{array}$ & $\begin{array}{l}\text { Kaku, fanatic, } \\
\text { skeptic, } \\
\text { prejudice, } \\
\text { tertutup, arogan, } \\
\text { komunal, } \\
\text { ekslusif, } \\
\text { intoleran, } \\
\text { sarkastik, "group } \\
\text { truth" claim”, } \\
\text { antipasti/ kurang } \\
\text { empatik pada } \\
\text { non- kelompok, } \\
\text { anti- } \\
\text { militant, kritik, } \\
\text { sangat loyal pada } \\
\text { organisasi } \quad \text { in } \\
\text { group feeling) }\end{array}$ & $\begin{array}{l}\text { Adaptif, loyal, } \\
\text { terbuka, inklusif, } \\
\text { akomodatif } \\
\text { terhadap lokalitas, } \\
\text { pertahankan } \\
\text { budaya } \\
\text { lingkungan, } \\
\text { dukung pemerintah } \\
\text { dan kebijakan- } \\
\text { kebijakannya. } \\
\text { Menerima konsep } \\
\text { negara bangsa } \\
\text { yang plural dan } \\
\text { multicultural. }\end{array}$ & $\begin{array}{lr}\begin{array}{l}\text { Adaptif, } \\
\text { rasional, }\end{array} & \begin{array}{r}\text { kritis, } \\
\text { terbuka, }\end{array} \\
\text { demokratis, } & \text { toleran, } \\
\text { kritis, } & \text { pembela } \\
\text { minoritas, } & \text { wordly- } \\
\text { concerned", } & \text { sekuler, } \\
\text { inklusif, } & \text { agungkan } \\
\text { kebebasan } & \text { dan } \\
\text { kesetaraan. } & \end{array}$ \\
\hline
\end{tabular}

\section{B. Nahdlatul Ulama}

Ada banyak faktor yang melatar belakangi berdirinya NU. Di antara faktor itu adalah perkembangan dan pembaharuan pemikiran Islam yang menghendaki pelarangan segala bentuk amaliah kaum Sunni. Sebuah pemikiran agar umat Islam kembali pada ajaran Islam "murni", yaitu dengan cara umat Islam melepaskan diri dari sistem bermadzhab. Bagi para kiai pesantren, pembaruan pemikiran keagamaan sejatinya tetap merupakan suatu keniscayaan, namun tetap tidak dengan meninggalkan tradisi keilmuan para ulama terdahulu yang masih relevan. Untuk itu, Jam'iyah Nahdlatul Ulama cukup mendesak untuk segera didirikan.

Untuk menegaskan prinsip dasar organisasi ini, maka K.H. Hasjim Asy'ari merumuskan kitab Qanun Asasi(prinsip dasar), kemudian juga merumuskan kitab I'tiqad Ahlussunnah Wal Jamaah. Kedua kitab tersebut kemudian diwujudkan dalam khittah NU, yang dijadikan sebagai dasar dan 
rujukan warga NU dalam berpikir dan bertindak dalam bidang sosial, keagamaan dan politik.

Nahdlatul Ulama sebagai Jam'iyah Diniyah adalah wadah bagi para Ulama dan pengikut-pengikutnya yang didirikan pada tanggal 16 Rajab 1344 H/ 31 Januari 1926 M dengan tujuan untuk memelihara, melestarikan, mengembangkan, dan mengamalkan ajaran Islam yang berhaluan Ahlussunnah wal Jama'ah dan menganut salah satu Madzhab Empat, masing-masing Imam Abu Hanifah An Nu'man, Imam Malik bin Anas, Imam Muhammad bin Idris Asy Syafi'I, dan Imam Ahmad bin Hanbal, serta untuk mempersatukan langkah para Ulama dan pengikutpengikutnya dalam melakukan kegiatan-kegiatannya yang bertujuan untuk menciptakan kemaslahatan masyarakat, kemajuan bangsa, dan ketinggian harkat dan martabat manusia. ${ }^{4}$ Salah satu pandangan Ahl Al-Sunnah wal Jama'ah memang ada yang menyangkut soal tradisi. Bahkan menurut konsep Ahlussunnah wal Jama'ah, tradisi haruslah dilestarikan, walaupun caranya bisa saja dengan melakukan modifikasi bahkan perubahan tertentu. ${ }^{5}$

Dengan demikian, Nahdlatul Ulama merupakan gerakan keagamaan yang bertujuan untuk ikut membangun dan mengembangkan insan dan masyarakat yang bertaqwa kepada Allah SWT, cerdas, terampil, berakhlaq mulia, tenteram, adil dan sejahtera. Nahdlatul Ulama mewujudkan cita-cita dan tujuannya melalui serangkaian ikhtiyar yang didasari oleh r-dasar faham keagamaan yang membentuk kepribadian betrcirikhas Nahdlatul Ulama. Inilah yang kemudian disebut Khittah Nahdlatul Ulama.

\section{Profil PCNU Kabupaten Nganjuk}

PCNU Kabupaten Nganjuk merupakan wilayah kepengurusan Nahdlatul Ulama di dalam wilayah jawa timur. PCNU Kabupaten Nganjuk

\footnotetext{
${ }^{4}$ Siradj, Said Aqiel, Ahlus Sunnah wal Jama'ah dalam lintas Sejarah, (Yogyakarta:LKPSM, 1998)

${ }^{5}$ Wahid, Abdurrahman, Muslim di tengah pergumulan, (Jakarta:Lappenas, 1981)
} 
membawahi 20 MWC NU se Kabupaten Nganjuk. Setiap MWC NU di Kabupaten Nganjuk mempunyai program unggulan yang berbeda-beda sesuai dengan ciri khas dan potensi daerah masing-masing. Dan seluruh program yang telah dilaksanakan merupakan program yang bertujuan untuk kemaslahatan umat dan syiar agama Islam. Misalnya di MWC NU Kertosono mempunyai program unggulan Abila yakni pembinaan anakanak yang tidak mampu, anak-anak yatim dan anak-anak yang terlantar. “Abila” merupakan singkatan dari Anak Binaan Lazisnu. Selain itu MWC NU Kertosono juga mempunyai program Klinik NU yang bergerak dalam bidang jasa kesehatan. Pasien yang tidak mampu dibebaskan dari biaya berobat di klinik NU MWC Kertosono. ${ }^{6}$

Lain halnya di MWC NU Prambon yang memiliki program unggulan "NU MART" yang bergerak dalam bidang perdagangan barangbarang kebutuhan pokok sehari-hari. Dimana hasil keuntungan dari "NU MART" akan dipergunakan untuk kegiatan sosial keagamaan. Seluruh warga NU dan masyarakat di daerah prambon khususnya dan wilayah Nganjuk pada umumnya dihimbau untuk berbelanja di "NU MART" untuk memenuhi kebutuhannya sehari-hari sekaligus beramal jariyah. PCNU Kabupaten Nganjuk mempunyai andil yang cukup besar dalam menjaga aqidah Ahlussunnah Wal Jamaah Annahdiyah di Kabupaten Nganjuk. Pesan Rahmatan lil 'alamin menjiwai karakteristik Islam Nusantara, sebuah wajah yang moderat, toleran, cinta damai, dan menghargai keberagaman. Islam yang merangkul bukan memukul; Islam yang membina bukan menghina; Islam yang memakai hati bukan memaki-maki; Islam yang mengajak taubat, bukan menghujat; dan Islam yang memberi pemahaman, bukan memaksakan. ${ }^{7}$

\footnotetext{
${ }^{6}$ Hasil wawancara dengan Ibu Nikmaturrohmah, S.Pd.I selaku penanggungjawab Abila Kertosono.

${ }^{7}$ Mujamil Qomar, "Islam Nusantara: sebuah alternative Model pemikiran, pemahaman, dan pengamalan Islam, “ 204
} 
128 - 147 | Tafhim Al-‘Ilmi, September 2019

\section{Implementasi Mabadi Khaira Ummah NU di Kabupaten Nganjuk.}

Nahdlatul Ulama' merupakan organisasi Islam dengan Ideologi Ahlusunnah Waljamaah An Nahdiyah. Nilai-nilai yang dianut pada dasarnya berisi tiga pokok ajaran yaitu; pertama ajaran ketauhidan atau keimanan sebagai dasar yang paling asasi dan pangkal tolak sebagai tingkah perbuatan ditujukan kepada paham Asy'ari dan Almaturidi. Kedua, paham fiqh atau syari'at Islam sebagai landasan normatif bagi segala amal ibadah yang berhubungan secara vertical (Tuhan) dan horizontal(sesama manusia, mengikuti paham bermadzhab yang dirujukkan kepada imam empat, yaitu Syafi'I, Maliki, Hambali, dan Hanafi). Ketiga, paham Tasawuf sebagai landasan sikap mental bagi segala amal perbuatan dirujukkan kepada Abu Qasim Al-Baghdadi, dan etikanya kepada Al-Ghazali. ${ }^{8}$

Muktamar (dulu disebut kongres) Nahdlatul Ulama ke-13, tahun 1935 antara lain memutuskan, bahwa kendala utama yang menghambat kemajuan umat melaksanakan amar ma'ruf nahi mungkar dan menegakkan agama adalah karena kemiskinan dan kelemaahan ekonomi. Oleh karena itu, muktamar mengamanatkan kepada PBNU (dulu namanya HBNO) untuk mengadakan gerakan penguatan ekonomi warga. Para pemimpin NU waktu itu menyimpulkan bahwa kelemahan ekonomi ini bermula dari lemahnya Sumber Daya Manusianya (SDM). Setelah diadakan pengkajian, disimpulkan ada beberapa prinsip ajaran Islam yang perlu ditanamkan kepada warga NU agar bermental kuat sebagai modal perbaikan sosial ekonomi yang disebut dengan Mabadi'Khairul Ummah, atau langkah awal membangun umat yang baik. Lima prinsip Mabadi' Khairul Ummah adalah:

1. As-Shidqu (Kejujuran, kebenaran, kesungguhan, dan keterbukaan)

Al-Shidqu berarti jujur, benar, keterbukaan, tidak bohong, sertasatunya hati antara kata dan perbutan. Setiap warga nahdhliyyin,mula-mula dituntut jujur kepada diri sendiri, kemudian

\footnotetext{
${ }^{8}$ Imron Arifin, Kepemimpinan Kyai, (Malang:Kalimashada, 1993), h 29
} 
kepadaorang lain. Dalam mu'amalah dan bertransaksi harus mengikuti sifatal-shidqu ini sehingga lawan dan kawan kerjanya tidak khawatirtertipu. Itulah yang dilakukan oleh Rasulullah saat menjalankanbisnis Sayyidatina Khadijah. Dari sikap inilah, beliau memperoleh kesuksesan yang besar. Padahal itu memang menjadi

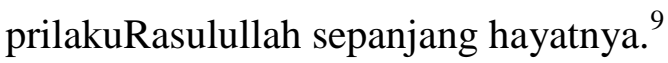

Warga NU sebagai pengikut Nabi Muhammad harus mengikutijejaknya. Bila melupakan dan meninggalkannya, pasti akan merugidan menderita kegagalan. Sikap al-shidqu ini terbukti juga bagianpenting dari kunci sukses kegiatan perekonomian modern. Jujur merupakan sifat keutamaan yang menjadi dasar dalam kehidupan bermasyarakat. Dengan kejujuran, setiap urusan dapat berjalan dengan tertib dan lancar sehingga tugas-tugas kemasyarakatan dapat terlaksana dengan baik dan dapat pula dipertanggungjawabkan. Selain itu, sifattt jujur dapat mengangkat derajat seseorang, karena sifat jujur itu dapat menjadikan seseorang dipercaya dan dihormati. Sebaliknya, orang yang suka berbohong dan berpura-pura, akan semakin dijauhi orang lain. Allah SWT berfirman dalam surat At-Taubah ayat 119:

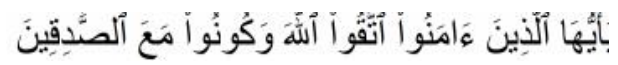

Artinya:"Hai orang-orang yang beriman bertakwalah kepada Allah, dan hendaklah kamu bersama orang-orang yang benar”.

Ayat tersebut menyerukan semua orang beriman agar bertaqwa kepada Allah SWT serta masuk bersama dalam kelompok orang-orang yang benar baik dalam sikap, ucapan, maupun perbuatan. Masuk dalam kelompok tersebut berarti meneladani mereka. Kalaupun tidak secara sempurna maka paling sedikit meniru sebagian sifat-sifat mereka, karena siapa yang selalu bersama sesuatu, maka sedikit demi sedikit ia akan terbiasa dengannya. Apabila kita masuk dalam kelompok orang-orang yang benar baik dalam sikap, ucapan,

\footnotetext{
${ }^{9}$ As'ad Thoha DKK. 2013. Pendidikan Aswaja dan ke NUan. Sidoarjo. Al-Maktabah- PW LP Maarif NU Jatim 2013
} 
dan perbuatan, maka kita akan terbiasa dalam kebenaran. Ayat-ayat tersebut juga memerintahkan agar selalu berucap dan bertindak benar. Kebenaran mengantar kepada kebajikan dan kebajikan mengantar ke surga. Seseorang yang selalu berucap dan bertindak benar serta mencari yang benar pada akhirnya dinilai oleh Allah SWT. Kejujuran hendaknya dapat menjadi kepribadian dan karakter yang menjiwai setiap langkah kita dalam kehidupan bermasyarakat. Dengan prinsip As-Shidqu, maka setiap warga Nahdlatul Ulama senantiasa menjadi orang beriman yang selalu benar dan jujur dalam sikap, ucapan, perbuatan dan pemikiran.

Penerapan Sikap kejujuran oleh warga NU di Kabupaten Nganjuk ditunjukkan dalam berbagai hal, diantaranya yakni dalam hal pengelolaan keuangan dalam melaksanakan suatu kegiatan. Hal ini sangatlah penting untuk menumbuhkan rasa tanggung jawab yang tinggi dan memberikan contoh yang baik bagi generasi yang akan datang. Kejujuran juga ditanamkan sejak dini oleh warga NU melalui pendidikan formal, non formal dan informal. Nahdlatul Ulama telah memiliki lembaga pendidikan formal yang dikelola melalui LP Maarif NU. melalui lembaga tersebut konsep kejujuran ditanamkan kepada peserta didik yang menempuh pendidikan. Dalam pendidikan non formal, Nahdlatul Ulama mengajarkan kepada anak didik melalui lembaga pondok pesantren yang sudah berdiri jauh sebelum Indonesia merdeka. Pondok pesantren yang merupakan tempat menempa santri dalam bidang keilmuan agama telah terbukti melahirkan cendekiawan muslim yang berakhlakul karimah. Dalam pendidikan informal, warga Nahdlatul Ulama mengajarkan kejujuran kepada anak-anak mereka, saudara-saudara mereka dalam kehidupan sehari-hari.

2. Al-Amanah wal Wafa' bil Ahdi(Dapat dipercaya, setia, dan menepati janji)

Al-Amanah wa al-wafa' bi al- 'ahdi artinya dapat dipercaya memegang tanggung jawab dan memenuhi janji. Amanah juga salah 
satu sifat Rasul. Amanah menjadi hal penting bagi kehidupan seseorang dalam pergaulan memenuhi kebutuhan hidup. Sebelum diangkat menjadi rasul, nabi Muhammad mendapat gelar Al-Amin dari masyarakat karena diakui sebagai orang yang dapat diserahi tanggungjawab. Salah satu di antara syarat warga NU agar sukses dalam menjalankan kehidupan haruslah tepercaya dan menepati janji serta disiplin memenuhi agenda. Bila orang suka khianat dan ingkar janji, pasti tidak akan dipercaya baik oleh kawan kerja ataupun relasi. Pelanggan akan memutus hubungan dan kawan kerja akan menjauh. Al-amanah dan wafa' bi al- 'ahdi memang merupakan bagian penting dari keberhasilan perekonomian. Sebab itulah sikap profesional modern yang berhasil pada masa kini. Bila semua orang tidak pernah menepati janjinya, tidak acuh pada tanggungjawabnya, mempermainkan patokan-patokan moralitas, maka akan dapat dibayangkan betapa hancurnya kehidupan masyarakat. ${ }^{10}$

Sebagai salah satu pilar utama Mabadi Khaira Ummah, maka Al-Amanah wal Wafa' bil Ahdi memiliki beberapa arti yaitu:

a. Dapat dipercaya. Sifat ini biasa melekat pada seseorang yang dapat melaksanakan tugas yang menjadi tanggung jawabnya, baik yang bersifat keagamaan maupun kemasyarakatan.

b. Setia. Yang berarti kepatuhan dan ketaatan kepada Allah dan juga terhadap pemimpin sepanjang tidak memerintahkan berbuat maksiat.

c. Menepati Janji. Yaitu melaksanakan semua perjanjian baik yang dibuatnya sendiri maupun yang dibuat bersama orang lain, misalnya janji pemimpin terhadap yang dipimpin, janji dengan sesama anggota masyarakat, janji dengan sesama teman, janji dengan sesama anggota keluarga dan lain-lain. Dalam Al-Qur'an surat An-Nisa' ayat 58 Allah SWT berfirman:

\footnotetext{
${ }^{10}$ Noeng Muhajir, Ilmu Pendidikan dan Perubahan Sosial suatu Teori Pendidikan, (Yogyakarta; Rake Sarasin, 1993) h, 12
} 


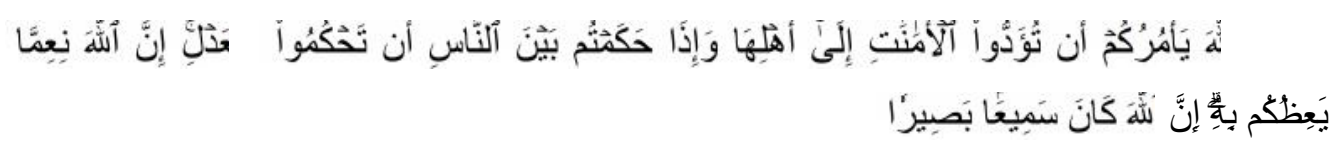

Artinya:"Sesungguhnya Allah menyuruh kamu menyampaikan amanat kepada yang berhak menerimanya, dan (menyuruh kamu) apabila menetapkan hukum di antara manusia supaya kamu menetapkan dengan adil. Sesungguhnya Allah memberi pengajaran yang sebaikbaiknya kepadamu. Sesungguhnya Allah adalah Maha Mendengar lagi Maha Melihat”.

Ayat tersebut diatas menekankan pentingnya menunaikan amanat dalam berbagai ragamnya kepada yang berhak/ pemiliknya. Artinya, sebagai hamba Allah kita diperintahkan untuk melaksanakan tanggung jawab dengan sebaik-baiknya. Apabila kita mendapatkan tugas dan telah menyetujui tugas itu, maka kita harus benar-benar dapat mempertanggungjawabkannya dengan baik sesuai dengan ketentuan yang berlaku. Inilah yang dimaksud dalam ungkapan AlAmanah yang menjadi salah satu butir Mabadi Khaira Ummah, yakni setia dan dapat dipercaya dalam melaksanakan tugas dan tanggung jawab.

Sedangkan Al Wafa bil 'Ahadi dasarnya adalah firman Allah dalam QS Al-Maidah ayat !:

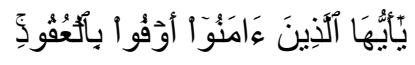

Artinya: Hai orang-orang yang beriman, penuhilah aqad-aqad itu.

Ayat tersebut memerintahkan kepada orang yang beriman agar memenuhi segala macam perjanjian, baik perjanjian yang berhubungan dengan Allah SWT yang terjalin melalui pengakuan keimanan kepada Rasulnya atau melalui nalar yang dianugerahkanNya, dan juga memenuhi perjanjian dengan sesama manusia selama tidak menjurus pada pengharaman yang halal atau penghalalan yang haram. 
Oleh karena itu sebagai orang yang beriman, kita harus selalu menepati janji. Janji itu kadang dibuat dengan orang lain secara tertulis atau hanya dengan lisan saja. Janji terkadang juga dibuat dengan dirinya sendiri, dan juga janji dengan Allah. Semua janji itu harus ditepati dan tidak boleh di khianati. Setiap orang mukmin dengan membaca Syahadat, berarti ia berjanji kepada Allah untuk beribadah hanya kepada-Nya. Dalam sebuah organisasi, anggotanya secara otomatis harus berjanji untuk tunduk kepada peraturan organisasi yang diikutinya. Dengan demikian, maka ia harus bisa melaksanakan peraturan itu dengan sebaik-baiknya.

Bentuk pelaksanaan sikap Al-Amanah wal Wafa' bil Ahditercermin dalam sikap dan perbuatan pengurus NU yang dapat dipercaya, setia, dan menepati janji sesuai dengan apa yang mereka ucapkan ketika di bai'at sebagai pengurus NU. Penerapan konsep AlAmanah wal Wafa' bil Ahdi juga meliputi kegiatan kontrol terhadap pemerintahan daerah. Nahdlatul Ulama memberikan masukan dan mengingatkan pemimpin apabila melakukan kesalahan ataupun tidak menepati janjinya. Hal ini penting dilakukan agar pemimpin tetap berada dijalan yang lurus dan menepati janjinya sebelum terpilih. ${ }^{11}$

3. Al A'dalah(adil, memberikan hak dan kewajiban secara proporsional)

Al-Adalah berarti bersikap adil, proporsional, objektif dan mengutamakan kebenaran. Setiap warga nahdliyyin harus memegang kebenaran objektif dalam pergaulan untuk mengembangkan kehidupan. Orang yang bersikap adil meski kepada diri sendiri akan dipandang orang lain sebagai tempat berlindung dan tidak menjadi ancaman. Warga nahdliyyin yang bisa menjadi pengayom bagi masyarakat sekigus memudahkan dan membuka jalan kehidupannya. Sikap adil juga merupakan ciri utama penganut sunni-nahdliyyin dalam kehidupan bermasyarakat. Dan bila ini benar-benar mampu menjadi karakter warga nahdliyyin, berarti wujud dari prinsip risalha

\footnotetext{
${ }^{11}$ Wawancara dengan Bpk KH. Bisri Hisyam (Tanfidiyah PCNU Kab Nganjuk)
} 
kenabiah rahmatan lil 'alamin yang berarti bukan hanya bermanfaat bagi diri sendiri atau golongan, akan tetapi penebar cinta kasih kepada semua orang. Ini penting bagi suksesnya seorang dalam mengarungi kehidupan.

Setiap orang punya hak dan kewajiban. Hak adalah sesuatu yang mesti diperolehnya, sedangkan kewajiban adalah sesuatu yang harus dikerjakannya. Pemberian hak dan pelaksanaan kewajiban bagi setiap orang harus disesuaikan dengan proporsinya masingmasing.Sikap adil merupakan sendi kehidupan dalam bermasyarakat. Dalam hubungan antar manusia sikap adil itu sangat diperlukan, karena dapat menjadikan ketertiban dalam suatu tatanan sosial. Setiap orang yang adil akan merasa puas dengan kedudukannya sendiri ia akan menyadari kewajibannya bila haknya sudah dipenuhi. Ia pun tidak akan iri kepada orang lain, karena ia mengetahui hak dan kewajiban orang lain itu pasti berbeda. Sebaliknya, apabila seseorang selalu menuntut lebih dari haknya, sementara ia enggan memenuhi kewajibannya, maka hal ini akan menyebabkan tatanan masyarakat yang terganggu. Sebab yang terjadi adalah iri hati dari masing-masing anggota masyarakat karena saling menuntut haknya. Oleh sebab itu, setiap anggota masyarakat harus selalu bersikap adil dengan saling menyadari hak dan kewajibannya masing-masing.

Lebih penting lagi, setiap pemimpin dituntut supaya bersikap adil dengan memberikan hak dan kewajiban bagi setiap orang yang menjadi bawahannya. Dalam QS. Al-Maidah ayaut 8 Allah SWT berfirman:

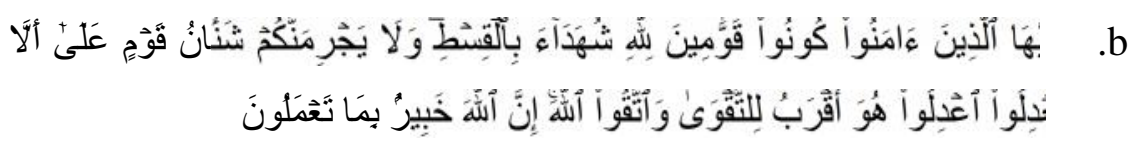

Artinya:"Hai orang-orang yang beriman hendaklah kamu jadi orangorang yang selalu menegakkan (kebenaran) karena Allah, menjadi saksi dengan adil. Dan janganlah sekali-kali kebencianmu terhadap sesuatu kaum, mendorong kamu untuk 
berlaku tidak adil. Berlaku adillah, karena adil itu lebih dekat kepada takwa. Dan bertakwalah kepada Allah, sesungguhnya Allah Maha Mengetahui apa yang kamu kerjakan”.

Ayat tersebut diatas memerintahkan kepada orang mukmin agar selalu bersungguh-sungguh menjadi pelaksana-pelaksana sempurna terhadap tugas-tugas yang mereka emban. Caranya adalah dengan upaya menegakkan kebenaran semata-mata karena Allah SWT serta menjadi saksi dengan adil. Bahkan Allah SWT mengingatkan agar kebencian terhadap seseorang atau sekelompok orang jangan sampai mendorong untuk berlaku tidak adil, karena sikap adil itu lebih dekat kepada taqwa yang sempurna. Berlaku adil dalam segala hal sangat dibutuhkan untuk mencapai kehidupan yang tenteram dan bahagia di dunia dan kelak di akhirat(as-sa'adah fid darain). Itulah sebabnya, maka berlaku adil merupakan jalan yang terdekat menuju taqwa kepada Allah SWT. Keadilan harus ditegakkan tanpa pilih kasih atau pandang bulu. Begitu mulianya menegakkan keadilan, sehingga Rasulullah SAW menyebutkan bahwa orang yang berlaku adil akan memperoleh derajat yang mulia di sisi Allah SWT.

Setiap warga Nahdlatul Ulama dituntut agar senantiasa bersikap adil dalam setiap kegiatan yang dilakukannya, baik dalam lingkungan keluarga, masyarakat sekitarnya, maupun dalam komunitas lain dimana dia berada. selain itu dalam hal pemerintahan di Kabupaten Nganjuk, PCNU secara aktif melakukan kontrol terhadap kebijakan-kebijakan yang diterapkan oleh pemerintah daerah agar selalu Istiqomah dalam hal keadilan. ${ }^{12}$

4. At Ta'awun( Tolong-menolong, setia kawan, dan gotong-royong dalam kebaikan dan ketaqwaan)

Berarti tolong menolong atau saling menolong antara sesama dalam kehidupan. Ini sesuai dengan jati diri manusia sebagai

\footnotetext{
${ }^{12}$ Wawancara dengan Bapak KH. Ali Mustofa Said(Syuriah PCNU Kab Nganjuk)
} 
makhluk sosial yang tidak bisa hidup tanpa ada kerjasama dengan makhluk lainnya: sesama manusia, dengan binatang, maupun dengan alam sekitar. Setiap warga nahdliyyin harus menyadari posisinya di tengah masyarakat, harus bisa menempatkan diri, bersedia menolong dan butuh pertolongan. Dalam ajaran agama islam, tolong menolong merupakan prinsip bermu'amalah. Karena itu dalam jual beli misalnya, kedua belah pihak harus mendapat keuntungan, tidak boleh ada satu pihak yang dirugikan. hal ini sesuai dengan prinsip ta'awun, yakni pembeli menginginkan barang sedangkan penjual menginginkan uang. Bila setiap bentuk muamalah menyadari prinsip ini muamalah akan terus berkembang dan lestari. Jalan perekonomian pasti akan terus lancar. Bila prinsip ta'awun ini ditinggalkan, maka akan merugikan diri sendiri dan dalam bermuamalah akan mengalami banyak kendala.Prinsip ini juga berfungsi dan berperan besar sebagai upaya mengembangkan moralitas dan penanaman nilai-nilai, baik nilai-nilai insani maupun nilai-nilai Ilahi. ${ }^{13}$ Bahkan dalam hal ini Noeng Muhajir menegaskan, bahwa manusia bisa survive disebabkan adanya komitmen pada nilai-nilai moral.

Dalam QS. Al-Maidah ayat 2 Allah SWT berfirman:

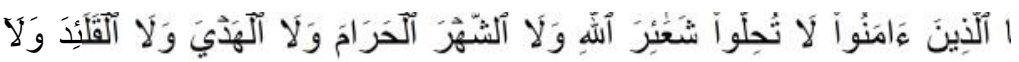

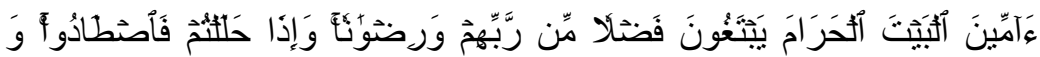

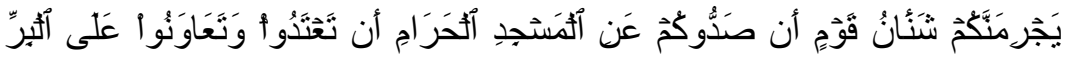

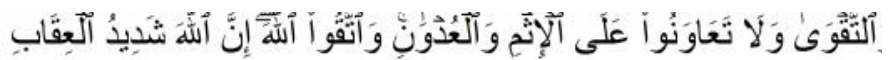

Artinya:"Hai orang-orang yang beriman, janganlah kamu melanggar syi'ar-syi'ar Allah, dan jangan melanggar kehormatan bulan-bulan haram, jangan (mengganggu) binatangbinatang had-ya, dan binatang-binatang qalaa-id, dan jangan (pula) mengganggu orang-orang yang mengunjungi Baitullah sedang mereka mencari kurnia dan keridhaan dari Tuhannya dan apabila kamu telah menyelesaikan ibadah

\footnotetext{
${ }^{13}$ Zakiah Drajat, Pendidikan Islam dalam Keluarga dan Sekolah,(Jakarta:Ruhama, 1994)h, 21
} 
Mohamad Umar Fauzi, Implementasi Konsep Mabadi... | 137 - 147

haji, maka bolehlah berburu. Dan janganlah sekali-kali kebencian(ти) kepada sesuatu kaum karena mereka menghalang-halangi kamu dari Masjidilharam, mendorongmu berbuat aniaya (kepada mereka). Dan tolongmenolonglah kamu dalam (mengerjakan) kebajikan dan takwa, dan jangan tolong-menolong dalam berbuat dosa dan pelanggaran. Dan bertakwalah kamu kepada Allah, sesungguhnya Allah amat berat siksa-Nya."

Ayat tersebut menegaskan pentingnya tolong-menolong dalam kebajikan dan ketaqwaan, serta melarang keras kerja sama dalam kedurhakaan. Tolong-menolong atau kerja sama itu dapat dijalin dengan siapapun baik muslim maupun non muslim, selama tujuannya adalah kebajikan baik muslim maupun non muslim, selama tujuannya adalah kebajikan dan ketaqwaan.

Begitu pentingnya kerja sama dan tolong menolong itu dalam kebajikan dan ketaqwaan, Rasulullah SAW mengibaratkan keterkaitan antara sesama orang beriman bagaikan sebuah bangunan yang saling menguatkan. Beliau bersabda:

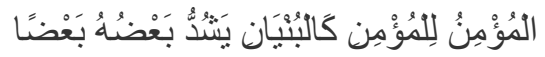

Artinya:"Orang mukmin dengan orang mukmin yang lain seperti sebuah bangunan, sebagian menguatkan sebagian yang lain."

( HR. Bukhari, Muslim, dan Tirmidzi)."

Harus disadari bahwa manusia diciptakan oleh Allah dalam kondisi tidak sempurna dan memiliki kelemahan-kelemahan, sehingga ia membutuhkan pertolongan orang lain. Pemimpin butuh bantuan dan dukungan rakyat yang dipimpinnya, sebaliknya rakyat membutuhkan figure pemimpin yang dapat melindungi dan mengayomi mereka. Orang kaya membutuhkan orang miskin untuk mengurus dan mengerjakan usahanya, sebaliknya orang miskin membutuhkan orang kaya untuk memberikan pekerjaan. Demikian juga pedagang 
membutuhkan pembeli untuk menawarkan dagangannya, sebaliknya pembeli membutuhkan pedagang untuk memenuhi kebutuhan hidupnya sehari-hari, dan seterusnya.

Singkat kata, setiap orang harus menyadari bahwa dirinya adalah lemah dan tidak bisa lepas dari bantuan orang lain. Pada suatu saat seseorang membutuhkan bantuan orang lain, dan pada saat yang lain ia akan dibutuhkan orang lain. Disinilah pentingnya sikap saling tolong menolong dan saling membantu sesama manusia, sehingga kehidupan bermasyarakat akan berjalan dengan seimbang, harmonis, dan terjalin rasa persaudaraan yang kokoh.

Semua warga Nahdlatul Ulama harus memiliki kesadaran dan kepekaan ketika melihat orang lain berada dalam kesulitan untuk segera membantu dan menolongnya tanpa harus diminta. Apalagi ketika ada orang yang minta bantuan, maka tidak boleh menolaknya. Namun satu hal yang harus diingat, bahwa pertolongan dan bantuan itu harus dilakukan dengan ikhlas, tanpa merasa tertekan, dan tanpa pamrih.

Prinsip tolong-menolong merupakan suatu keharusan dan kewajiban yang harus dilakukan oleh warga NU. hal ini tercermin dalam setiap sendi kehidupan warga NU yang saling gotong royong dalam mensukseskan setiap kegiatan yang positif. Yakni ketika ada kegiatan pengajian umum, kegiatan sosial dan kemasyarakatan serta kegiatan lainnya.

Tolong menolong merupakan perintah Allah kepada umat Islam. Hal ini sangatlah penting karena sejatinya manusia merupakan makhluk sosial yang tidak bisa hidup sendiri. Manusia yang satu pasti membutuhkan manusia yang lainnya sebagai upaya untuk memenuhi kebutuhan hidupnya. Seseorang yang kaya pasti membutuhkan manusia yang miskin dan manusia yang miskin juga membutuhkan manusia yang kaya. Misalnya seorang pengusaha pasti membutuhkan pekerja untuk menjalankan usahanya, dan pekerja atau orang miskin 
juga membutuhkan pengusaha untuk mendapatkan pekerjaan. Orang yang kaya membutuhkan orang miskin sebagai sarana untuk mensedekahkan hartanya dan orang miskin membutuhkan orang kaya untk membantu memenuhi kebutuhan hidupnya. Dan masih banyak contoh lainnya.

5. Al-Istiqamah ( Keajegan berada di jalur yang ditentukan Allah dan Rasulullah serta tuntunan dari Ulama' Salafus Sholeh)

Al-istiqamah adalah sikap mantap, tegak, konsisten, dan tidak goyah oleh godaan yang menyebabkan menyimpang dari aturan hukum yang perundangan. Di dalam Alqur'an dijanjikan kepada orang yang beriman dan beristiqamah, akan memperoleh kecerahan hidup, terhindar dari ketakutan, dan kesusahan sehingga ujungnya mendapatkan kebahagiaan. Untuk mendapatkan sukses hidup warga nahdliyyin juga harus memegang konsep istiqamah ini, tahan godaan, dan tidak tergiur melakukan penyimpangan yang hanya menjanjikan kenikmatan sesaat dan kesengsaaraan yang panjang. Sikap konsisten akan membuat kehidupan menjadi tenang yang bisa menumbuhkan inspirasi, inisiasi, dan kreasi yang bisa mengatasi segala tantangan dan rintangan. Selain itu, ciri khas warga Nahdlatul Ulama adalah sangat taat kepada para Ulama sebagai panutan dalam menjalani kehidupan. Dalam pandangan Nurkholis Majid, Ulama atau Kyai dengan pesantrennya dianggap sebagai sesuatu yang dapat diibaratkan sebagai kerajaan kecil, dimana kyai merupakan sumber mutlak dari kekuasaan dan kewenangan dalam kehidupan dan lingkungan pesantren. ${ }^{14}$

dalam QS. Fusshilat ayat 30 Allah SWT berfirman:

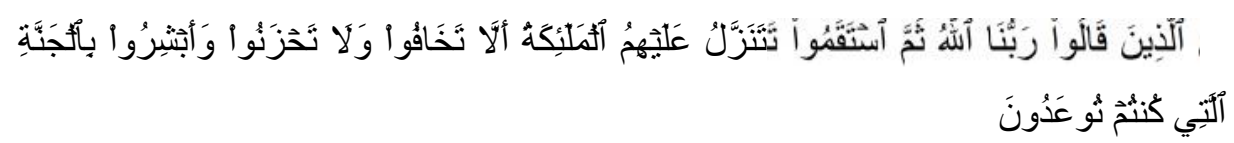

\footnotetext{
${ }^{14}$ Nurkholis Madjid,” Islam Doktrin dan Peradaban, (Jakarta: Yayasan Paramadina, 1997)h. $77-78$
} 
Artinya:"Sesungguhnya orang-orang yang mengatakan: "Tuhan kami ialah Allah" kemudian mereka meneguhkan pendirian mereka, maka malaikat akan turun kepada mereka dengan mengatakan: "Janganlah kamu takut dan janganlah merasa sedih; dan gembirakanlah mereka dengan jannah yang telah dijanjikan Allah kepadamu"

Ayat tersebut menyatakan bahwa istiqamah(konsisten) dalam persesuaian amal perbuatan dengan ikrar pengakuan ke-Tuhanan Allah lebih tinggi Allah lebih tinggi derajatnya daripada ikrar itu sendiri. Konsistensi yang terpuji itu bersifat mantap dan berlanjut dalam waktu yang berkepanjangan hingga akhir hayat.

Setiap perbuatan baik seharusnya dilakukan dengan hati yang mantap, dan tidak mudah terpengaruh oleh keadaan yang membelokkan dari tujuan utama perbuatan itu. Selain itu, perbuatan yang baik juga harus dilakukan secara terus-menerus dan tidak mudah larut dengan keadaan yang dihadapi. Perbuatan yang baik tidak boleh dilakukan hanya sesaat ketika dalam keadaan senang, kemudian berangsur-angsur melemah, dan tidak mau berbuat lagi. Karena hal tersebut bertentangan dengan sifat Istiqamah yang menjadi salah satu pilar Mabadi Khaira Ummah.

Dalam sebuah Hadis Rasulullah SAW bersabda:

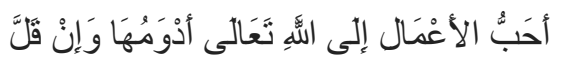

Artinya:"Amalan yang paling dicintai oleh Allah Ta'ala adalah amalan yang kontinu walaupun itu sedikit."

Istiqamah akan menghindarkan dari kesulitan hidup. Program dasar Nahdlatul Ulama di bidang kesejahteraan ekonomi ditujukan untuk mewujudkan kesejahteraan yang merata, kesejahteraan umat atas dasar perikemanusiaan dan akhlakul karimah. Tujuan ini meliputi seluruh warga Nahdlatul Ulama, umat Islam, dan masyarakat pada umumnya. 
Ajaran agama Islam merupakan ajaran yang bersumber dari Allah dan diajarkan oleh Rasulnya melalui perantara Malaikat Jibril. Setelah Rasulullah wafat maka pewarisnya adalah para sahabat, dan ketika para sahabat telah tiada maka pewarisnya adalah Tabiin dan seterusnya sampai dkepada para Ulama. Sehingga peran Ulama sebagai pewaris para Nabi dan Rasulullah tidak dapat terbantahkan oleh siapapun dan sampai kapanpun.

Selama umat Islam berpegang teguh kepada ajaran dan tuntunan para Ulama maka umat tersebut sama dengan menjalankan ajaran para Nabi dan Rasulullah. Hal inilah yang menjadi dasar beragama dan beribadah yang dilakukan oleh warga Nahdiyin sejak dulu sampai sekarang. Ketersambungan sanad keilmuan menjadi azas pokok yang dipegang oleh warga NU untuk memilih dan memilah Ulama yang benar-benar pewaris para Nabi dan Rasul. Amaliyahamaliyah yang dilakukan oleh warga NU merupakan amaliyah yang diajarkan oleh para Ulama NU sejak dahulu. Amaliyah yang dilaksanakan secara turun-temurun ini dilaksanakan secara terusmenerus dan Istiqomah.

Amaliyah yang dilakukan oleh warga Nahdlatul Ulama dinilai sangat khas dengan ciri sangat kental dengan budaya di Indonesia. Salah satu contohnya adalah pelaksanaan tahlilan sebagai upaya mendo'akan keluarga yang telah meninggal dunia. Upacara tujuh hari meninggalnya seseorang yang diisi dengan membaca kalimah-kalimah tayyibah secara berjamaah diyakini membawa keberkahan dan kebaikan bagi yang didoakan. ${ }^{15}$

\footnotetext{
${ }^{15}$ Wawancara dengan Bapak K. Sholahuddin( Tanfidiyah MWC NU Kec Lengkong Kab Nganjuk)
} 


\section{E. Relevansi Konsep "Mabadi Khaira Ummah NU” dan Moderasi Islam di Kabupaten Nganjuk.}

Manusia adalah makhluk yang dijadikan khalifah oleh Allah SWT dalam merumuskan hukum-hukum Ilahi, kemudian ia membuat kaidah, kodifikasi, dan mengaplikasikan hukum itu. Imam Ibnu Hazm AlAndalusi (384-456 H/ 994-1064 M) mengucapkan perkataannya yang tepat sekali tentang pengakuan kekuatan legislasi manusia yang ditugaskan menjadi khalifah itu, "Diantara hukum Allah SWT adalah memberikan hak perumusan hukum bagi selain Allah SWT". ${ }^{16}$

Konsep Mabadi Khaira Ummah yang telah ditetapkan dan diterapkan oleh Nahdlatul Ulama merupakan suatu prinsip dalam bersikap dan menjalani kehidupan sebagai umat Islam yang terbaik. Prinsip ini tentu lahir berdasarkan pertimbangan dari sesepuh Nahdlatul Ulama yang mengedepankan cinta terhadap NKRI dan Islam yang moderat. Sehingga konsep ini sangat layak untuk diterapkan di negara Indonesia yang majemuk demi mewujudkan Umat Islam yang terbaik serta menjaga keutuhan NKRI. Sikap moderat yang diambil oleh Nahdlatul Ulama tercermin dalam berbagai aspek diantaranya yakni aspek dalam bertauhid, amaliyah, dan penerapan Amar Ma'ruf Nahi Munkar.

Nahdlatul Ulama mengambil sikap moderat sebagai gerakannya dalam beragama. Hal ini sangat penting untuk dilakukan demi kemaslahatan umat manusia dalam beragama dan bermasyarakat. Dan untuk bersikap moderat warga Nahdlatul Ulama menerapkan Mabadi Khaira Ummah sebagai pegangan dalam melangkah. Warga Nahdlatul Ulama menjunjung tinggi ketaatan terhadap para Ulama. Hal ini sesuai dengan prinsip Al-Istiqamah yakni secara ajeg menjalankan fatwa-fatwa dan amaliyah-amaliyah para Ulama NU. Ketika Ulama NU menyatakan bahwa NKRI harga mati maka hal itulah yang diyakini kebenarannya dan dilaksanakan dengan penuh ketaatan oleh segenap warga NU.

\footnotetext{
${ }^{16}$ Ibnu Hazam, Al-Mufadhalah Bain ash-Shahabah, hlm.66. Teksnya ada pada Dr. Musthafa Helmy, Nizhamul-Khilahah Fil-Fikr Al-Islami (Dar ad -Da'wah Aleksander), hlm.171
} 
Selain itu, relevansi gerakan Mabadi Khaira Ummah NU dengan moderasi Islam ditunjukkan oleh segenap warga NU dalam pengamalan amaliyah-amaliyah NU kehidupan sehari-hari. Dengan memegang teguh prinsip Mabadi Khaira Ummah maka warga NU menjadi seseorang yang memiliki kepribadian yang kuat pendiriannya dalam mengedepankan kemaslahatan bersama dalam bersikap dan berperilaku. menjadi warga yang tidak kaku, tidak menjadi warga yang ekstrim, tidak gampang menyalahkan, menyelesaikan urusan dengan jalan terbaik, fleksibel, misalnya dalam mengadakan acara keagamaan tidak harus di masjid, bisa di lapangan ataupun dirumah warga. Warga NU menjadi warga yang moderat. Sehingga pilar-pilar Mabadi Khaira Ummah yang menjadi keseharian warga NU kemudian menumbuhkan sikap-sikap warga NU Nganjuk yang moderat, toleran dan saling menghargai perbedaan. ${ }^{17}$

Konsep Mabadi Khaira Ummah yang telah ditetapkan dan diterapkan oleh Nahdlatul Ulama merupakan suatu prinsip dalam bersikap dan menjalani kehidupan sebagai umat Islam yang terbaik. Prinsip ini tentu lahir berdasarkan pertimbangan dari sesepuh Nahdlatul Ulama yang mengedepankan cinta terhadap NKRI dan Islam yang moderat. Sehingga konsep ini sangat layak untuk diterapkan di negara Indonesia yang majemuk demi mewujudkan Umat Islam yang terbaik serta menjaga keutuhan NKRI. Sikap moderat yang diambil oleh Nahdlatul Ulama tercermin dalam berbagai aspek diantaranya yakni aspek dalam bertauhid, amaliyah, dan penerapan Amar Ma'ruf Nahi Munkar.

Nahdlatul Ulama mengambil sikap moderat sebagai gerakannya dalam beragama. Hal ini sangat penting untuk dilakukan demi kemaslahatan umat manusia dalam beragama dan bermasyarakat. Dan untuk bersikap moderat warga Nahdlatul Ulama menerapkan Mabadi Khaira Ummah sebagai pegangan dalam melangkah. Warga Nahdlatul Ulama menjunjung tinggi ketaatan terhadap para Ulama. Hal ini sesuai

\footnotetext{
${ }^{17}$ Wawancara dengan Bapak Wahyu Irfana, S.Pd.I (Wakil Direktur Aswaja Center Kab Nganjuk)
} 
dengan prinsip Al-Istiqamah yakni secara ajeg menjalankan fatwa-fatwa dan amaliyah-amaliyah para Ulama NU. Ketika Ulama NU menyatakan bahwa NKRI harga mati maka hal itulah yang diyakini kebenarannya dan dilaksanakan dengan penuh ketaatan oleh segenap warga NU. hal ini merupakan cirikhas Nahdlatul Ulama yang membedakannya dengan aliran atau kelompok Islam radikal lain. Islam satu itu hanya ada pada level Al-Qur'an. Namun Al-Qur'an (serta Hadis) membutuhkan rumusan yang rinci, sehingga ayat-ayatnya perlu ditafsirkan dan dijelaskan maksudnya. Hasilnya, berupa kemunculan penafsiran dan penjelasan yang berbeda-beda, kemudian menjadi madzhab atau aliran. ${ }^{18}$

Selain itu, relevansi gerakan Mabadi Khaira Ummah NU dengan moderasi Islam ditunjukkan oleh segenap warga NU dalam pengamalan amaliyah-amaliyah NU kehidupan sehari-hari. Dengan memegang teguh prinsip Mabadi Khaira Ummah maka warga NU menjadi seseorang yang memiliki kepribadian yang kuat pendiriannya dalam mengedepankan kemaslahatan bersama dalam bersikap dan berperilaku.

\section{F. Dampak Implementasi Mabadi Khaira Ummah NU di Kabupaten} Nganjuk .

Lima sikap dasar yang terkandung dalam Mabadi Khaira Ummah NU adalah sikap yang harus ditumbuhkan bagi setiap warga untuk mendapatkan keluhuran budi. Oleh sebab itu sikap ini harus ditumbuhkan dan dibiasakan sejak masa dini, sehingga kelak ketika seseorang sudah mandiri, sudah berinteraksi sosial ia akan menjadi warga masyarakat yang benar-benar dapat diteladani.

Ketika konsep ini diterapkan oleh warga NU maka keselarasan kehidupan masyarakat yang damai, tentram dan sejahtera dapat terwujud. Terbukti bahwa di wilayah Kabupaten Nganjuk menjadi wilayah yang kondusif. Hal ini terwujud karena setiap elemen warga masyarakat secara berkesinambungan mengamalkan nilai-nilai yang ada pada konsep Mabadi

\footnotetext{
${ }^{18}$ Mujamil Qomar, "Islam Nusantara: sebuah alternative Model pemikiran, pemahaman, dan pengamalan Islam, “ 204
} 
Khaira Ummah. Ketika terjadi perselisihan, perbedaan pendapat dan permasalahan-permasalahan lain maka akan diselesaikan secara adil, dan dengan petunjuk para Ulama. Inilah sikap moderat yang ditunjukkan oleh warga NU, sikap yang mengedepankan kemaslahatan umat Islam dalam kehidupan berbangsa dan bernegara. Berbeda dengan kelompok Islam radikal yang memaksakan kehendak agar seluruh umat Islam mengikuti pemahaman serta pelaksanaan ibadah seperti mereka. Dalam pemahaman mereka, Islam kaffah adalah Islam yang ada dan berkembang di Arab, sehingga seluruh komunitas Islam harus mengikuti pola keberagamaan yang mereka anut dan mereka praktikkan. Tradisi dan Adat Istiadat setempat bagi mereka merupakan bid'ah yang dapat mencemarkan Ajaran Islam yang sesungguhnya. Namun, Arabisasi atau proses mengidentifikasi diri dengan budaya Timur Tengah adalah akan tercerabutnya kita dari akar budaya kita sendiri.

\section{DAFTAR PUSTAKA}

Abduh, Imam Muhammad.1993. M. Al-A'mal al-Kamilah. Kajian dan Tahqiq:Dr. Muhammad Iamarah. Kairo

Abdurrahman Wahid, "musuh dalam selimut" sebuah pengantar pada buku Ilusi Negara Islam:Ekspansi gerakan Islam Trans Nasional di Indonesia, Jakarta: The Wahid Institute bekerja sama dengan Gerakan Bhinneka Tunggal Ika dan Ma' arif Institutem 2009

Achmad Satori Ismail DKK. Islam Moderat. Jakarta Timur. Pustaka Ikadi.2012

As'ad Thoha DKK. 2013. Pendidikan Aswaja dan ke NUan. Sidoarjo. AlMaktabah- PW LP Maarif NU Jatim 2013

Alvara Research Center.2016 .Potret Keberagaman Muslim Indonesia.Jakarta

Asep Saeful Muhtadi.Metode Penelitian Dakwah. Bandung. Pustaka Setia.2003

Beaudreau, Bernard C. 2012. A Humanistic Theory of Economic Behavior. The Journal of Socio-Economics, Vol. 41, 
146 - 147 | Tafhim Al-‘Ilmi, September 2019

Choirul Fuad Yusuf. Nasionalisme dalam Teks Keagamaan Indonesia Masa Depan. Jakarta.Jurnal Lektur. 2017

Creswell, John W. 1994. Research Design: Qualitative and Quantitative Approaches. California: Sage Publications, Inc

Fauzan Saleh, Teologi Pembaruan, (Jakarta:PT Serambi Ilmu Semesta, 2001)

Haidar M. Ali, 1993: Nahdlatul Ulama dan Islam di Indonesia- Pendekatan Fikih dalam Politik, Disertasi Doktor (Jakarta: Fakultas Pascasarjana IAIN Syarif Hidayatullah)

Hasil-hasil Musyawarah Nasional Alim Ulama Nahdlatul Ulama (Jakarta: Sekretariat Jenderal Pengurus Besar Nahdlatul Ulama, 2006)

Ibnu Hazam, Al-Mufadhalah Bain ash-Shahabah, hlm.66. Teksnya ada pada Dr. Musthafa Helmy, Nizhamul-Khilahah Fil-Fikr Al-Islami (Dar ad -Da'wah Aleksander)

Imarah. Muhammad.1999.Islam dan Pluralitas.Depok. Gema Insani

Imron Arifin, Kepemimpinan Kyai, (Malang:Kalimashada, 1993)

Lexy J. Moleong, Metodologi Penelitian Kualitatif, (Bandung: Remaja Rosdakarya, 2000)

Miles dan Huberman. Qualitatif Data Analysis. Tjetjep Rohendi Rohidi (penerjemah). Analisi Data Kualitatif. (Jakarta: UI Press, 1992)

Mujamil Qomar, "Islam Nusantara: sebuah alternative Model pemikiran, pemahaman, dan pengamalan Islam

Noeng Muhajir, Ilmu Pendidikan dan Perubahan Sosial suatu Teori Pendidikan, (Yogyakarta; Rake Sarasin, 1993)

Nurkholis Madjid," Islam Doktrin dan Peradaban, (Jakarta: Yayasan Paramadina, 1997)

S. Nasution, Metode Penelitian Naturalistik Kualitatif (Bandung: Tarsito, 2003)

Siradj, Said Aqiel, Ahlus Sunnah wal Jama'ah dalam lintas Sejarah, (Yogyakarta:LKPSM, 1998)

The Many Faces of Political Islam: Religion and Politich in the Muslim World

Wahid, Abdurrahman, Muslim di tengah pergumulan, (Jakarta:Lappenas, 1981) 
Mohamad Umar Fauzi, Implementasi Konsep Mabadi... | 147 - 147

Zakiah Drajat, Pendidikan Islam dalam Keluarga dan Sekolah,(Jakarta:Ruhama, 1994) 